Ивана Р. Јовановић

Филолошка гимназија

Београд
УДК: $316.77: 159.9$

https://doi.org/10.18485/uzdanica.2020.17.2.7

Прегледни рад

Примљен: 31. август 2020.

Прихваћен: 23. новембар 2020.

\title{
О НЕКИМ АСПЕКТИМА ПСИХОЛОГИЈЕ МЕДИЈСКЕ И ОПШТЕ КОМУНИКАЦИЈЕ
}

$A \bar{u} c \bar{u} р а к \bar{u}: У$ раду се теоријски разматра међусобно прожимање друштвене свести, културе, психологије и комуникације, са методолошке позиције у којој се појам културе и облици њене вербализације садржајно постављају као шири појмови од појма друштвене свести. Колективна свест се овде не схвата примарно као психолошка реалност, већ као социјална чињеница, амбијент у коме опстају језик, религија, наука, политика, медији и други варијетети друштвеног испољавања човековог, а област психолошког одређује се у колективној свести као систем норми. О психолошким моментима у медијској комуникацији, аутор истиче да стицање способности тумачења и критиковања медијских манипулација битно помаже појединцима да се оспособе за стварање бољег односа према доминантним медијима и култури уопште. Успостављањем спреге између културе медија, идеологије и психологије - закључак је ауторов - отвара се могућност хибридизације стварности и регресије хуманих идеала.

Кључне речи: психологија, комуникација, социологија, медиологија, манипулација.

\section{1. УВОДНА РАЗМАТРАҢА}

1. Интересовање да се открију и разумеју механизми функционисања и смисао људског комуницирања - како наводи 3. Томић (2003: 12-13) - „старо је колико и људско друштво”. Ова ауторка примећује и значај проучавања комуникације са психолошких и сродних аспеката истичући да комуникологија „надовезујући се на филозофску и лингвистичку традицију, а посебно на достигнућа психолингвистичких, социолингвистичких, семантичких, фонолошких, семиолошких истраживања - тематизује истраживања развојног, интеркултуралног и невербалног комуницирања, односно, питања домена важења различитих знаковних, а пре свега језичких, као и осталих симболичких система ${ }^{1}$ који структурирају процес комуникације”.

\footnotetext{
${ }^{1}$ О елементима овога симболичког процеса више у: М. Милетић, Н. Милетић 2012.
} 
2. О психолошкој и социјалној димензији комуникације још од античког периода наилазимо на опречне ставове. Врло се разликује Квинтилијанов став, на пример, од Аристотеловог ${ }^{2}$ К Квинтилијан се најпре позива на Цицерона, који на прво место поставља социјалну, а на друго - психолошку примереност израза теми, публици и самом кориснику језика. Аристотелово поимање говора, тј. текста, више одговара савременој текстологији, наратологији и вербатологији. Ово због тога што се текст може проучавати са гледишта информације коју садржи, са гледишта психологије његовог стварања - тј. као производа говорно-мисаоне делатности субјекта, па тек онда са позиција прагматичких (рецептивно-интерпретативних), и на крају, са аспекта његове структуре, говорне организације, стилистике и сл. (уп. Симић 1997: 166-167, 247).

а) У том смислу, П. Вучковић (1995: 114-117) о дискурсу суди управо са гледишта психолога и филозофа. По њему, говорник одабира појмове које слушалац треба да схвати, и речи које те појмове треба да изразе, а после тога следи планирање исказа. Уосталом, људи говоре да би произвели одређени ефекат код слушалаца, а језичка комуникација намеће проучавање значења у склопу тријаде: значење, намера говорника и интерпретација саговорника. Уколико томе додамо да се комуникација увек одвија у неком контексту, то ће и контекст постати незаобилазан фактор у објашњењу феномена значења (тачније: смисла). Основна разлика између лингвистичких правила и психолошких принципа лежи у томе што правила припадају категорији апсолутног, а психолошки принципи категорији релативног (уп. Ферт 1957, Сосир 1969, Леонтјев 1979, Катлин 1998).

б) Једини реални феномен усмерен на предмет споразумевања - јесте 'исказ' (Јовановић Симић, Симић 2015), а он упућује на моменте који постоје ван психолошког и језичког поља, и битно утичу на формирање поруке. 'Израз' се, међутим, односи на ентитет 'формиран у психи појединца', релативно независно од вањских момената (исп. Рубинштејн 1973: 523). Иако мисао и психолошки став не постоје потпуно херметизовани од вањског света, човек располаже моћима да активира свест, контролише своју вољу и емоције, или регулише унутрашње духовне потенције, и тако формира сопствену слику о предмету споразумевања. Тако 'прерађена' слика стварности (уп. Ворф 1979) уобличава се у поруку, или чини 'конотативну' пратњу поруке. Могла би се одавде извести теза да је 'израз' резултат активног психичког става говорника према предмету поруке, или према адресату.

3. 'Најпроточнији' и функционално-психолошки најразноврснији медијум комуникације - јесте човеков свакодневни живот, па је са овом чињеницом у вези и питање одређења природе свакодневице. Иако свакодневица 200-201.

${ }^{2}$ Исп. теоријски континуитет реторичког истраживања у: Удинг, Штајнбринк 2011: 
спада у људску културу, она је ипак одредљива помоћу специјалних облика духовног, материјалног и психолошког испољавања човековог.

а) Што се тиче језичког испољавања човековог у том контексту - оно се чини најкомплекснијим, особито због чињенице што се у свакодневном говору укрштају знање, искуство, емоције, друштвена свест, јавно мњење, па и медији (уп. Еко 1973: 38). С тим у вези, интересантно је запажање 3. Томић (2003: 12-13) да је суштина комуникације садржана у општењу, односно саопштавању одређеног садржаја (информације, поруке), те да „сваки културни феномен, од језика до осталих симболичких форми, медија комуницирања, па до одеће, хране, стамбеног простора, средстава транспорта, понашања, обреда, култова, ритуала - може бити предмет комуниколошких истраживања".

б) Овамо, наравно, спадају лепо опхођење, моралност, уравнотежена емоционалност итд. То значи да је у систем културе укључен са̂м човек, са свим особинама које је у њој стекао и које га за њу везују. „Урођена својства, диспозиције, дата су човеку као нека врста природе" - пише А. Хелер (1978: 40), и помаже нам да разграничимо културна од природних својстава човекових.

4. Дефинишући комуникацију преко средстава која користи, као што су форма (која је иначе под контролом субјекта), медијум (најпознатији као реч, књига, али и као графикон, цртеж и сл.), те и преко медија (практично, технолошких средстава масовне комуникације), 3. Томић (2003: 28) утврђује да „комуникација представља процес емитовања и примања знакова који имају одређено значење".

а) Разумљиво је, дакле, да комуникативни процес подразумева остваривање везе међу људима, а оне по својој суштини и структури могу бити директне или индиректне, али су увек одређене идејама, уверењима, психолошким позицијама комуникатора, мишљењима и сл. Иако је моћ говора биолошки дата човеку, комуникација, тј. њени облици и варијанте - морају се учити. У том смислу, комуникација је подложна нормативној регулацији.

б) Рут Бенедикт (1934) је утврдила да је мишљење и понашање припадника датог колектива условљено својеврсним устаљеним ${ }^{3}$ 'културним обрасцима'. Слично на културу гледа и С. Д. Форд (у: Стјуард 1981: 62): „Између физичке средине и људске делатности увек постоји један средњи члан, један скуп посебних циљева и вредности, склоп знања и уверења: другим речима, један културни образац". Два се цитирана става разликују по томе што је према потоњем читава култура један јединствени образац, а у првоме је реч о скупу или систему образаца из којих се састоји национална култура (уп. Белић 1998).

${ }^{3}$ Са овога су аспекта национално репрезентативне пословице, али и фразеологизми и друге фолклорне форме (исп. Јовановић 2006, Мршевић-Радовић 2008). 
5. Уз психологију сазнања, теоријски значај за нашу тему имају и Хартманова (1924) излагања о изворима сазнања. Интуитивно знање није нека 'трансценденција' чулне перцепције, већ је њена пратећа појава која за основу има подсвесне асоцијације из потиснутог или у датој прилици неактивног искуства које допуњује свест о догађају. Ове се асоцијације шире на колективне духовне структуре уз помоћ којих се знање систематизује и осмишљава ново сазнање (исп. Симић 2001). 'Систематизација' конвенционализоване, друштвено оверене мисаоне схеме или 'обрасца' подвргнута је увек одређеној хијерархији (исп. Симић 2010). Један од тих образаца делује у кругу психолошких вредности.

a) Рубинштејн ${ }^{4}$ (1973: 523) пак скреће пажњу на опасност идентификације мишљења, и његове психолошке форме - са језиком, који је, заправо, облички архаичнији. Наиме, језик поседује своју сопствену 'технику', а она је у међузависности са психолошком логиком, иако није идентична с њом. Тако, симултано или сукцесивно дати елементи запажања или утисака, битно условљавају комуникацију ${ }^{5}$. А оба процеса су психолошка, само у првом случају имамо описе датог скупнога садржаја, а у другом - нарацију.

б) „Посебно у овој групи стоје импресије, у којима преовлађује лични моменат $^{6}$ - сматра М. Павловић (1978: 17). С друге стране, с обзиром на односе елемената свести, који условљавају закључивање ${ }^{7}$ о нечем - имамо расправе”. У начелу, јединственост и целовитост искуствених и психолошких доживљаја могућа је једино на основи колективне свести, јер она уједињује у целину узајамно изолована стања индивидуалне свести.

\footnotetext{
4'Тематска прогресија' није ни замислива без 'тематског садржаја', дакле контакта исказне форме са предметом који описује (о томе више у: Јовановић Симић, Симић 2015). Да би се разумела та важна особеност предикативности, ваља упутити на разлику између општег значења и 'упућивања' на предмет разговора. „Однос речи и предмета чини основицу њеног значења - сматра Рубинштејн (1973: 510). - Али овај однос није непосредан већ је посредован помоћу општег семантичког садржаја речи, помоћу појма и слике”.

${ }^{5}$ О њима М. Павловић (1978: 17) говори као о „психолошко-језичким изражајима”.

${ }^{6} \mathrm{O}$ 'импресији' у комуникацији расправља Радојчић (1975), а о 'конотацији' као унутарсистемској појави која носи информацију о положају који заузимају језичке јединице у општем језичком систему, али и као о информацији о типу говорне сфере говоре Блумфилд (1970) и Симић (2001).

${ }^{7}$ Ауторска расуђивања прате делове текста који износе концептуалну информацију и изражавају се у облику судова, закључака, филозофских и психолошких уопштавања, у облику закључака и сажетака (исп. Јовановић Симић, Симић 2015).
} 


\section{2. НЕКА ЗАПАЖАЮА О ПСИХОЛОГИЈИ МЕДИЈСКЕ КОМУНИКАЦИЈЕ}

1. Са појмом 'опште културе' данас је нужно повезан и појам тзв. 'медијске културе'. По Д. Келеру (2004: 5-7) - она „користи и слику и звук. Различити медији $[\ldots]$ дају приоритет слици или звуку, или комобинацији ова два израза, усмеравајући своје дејство на широки спектар доживљаја, осећања и иде ја [...]”. Дакле, са аспекта савременог човека - мора се признати да је медијска култура ${ }^{8}$ истовремено и култура високе технологије, тзв. техно-култура, која практично ствара нови тип друштва у којем медији и технологија, посредством психологије, постају организацијски принципи. Сами медији представљају врло разноврсну и разуђену семиолошку материју, те значајно утичу на психолошко креирање људског ума, па се, природно, поставља питање има ли ту места за превентивно или терапеутско деловање (Келер 2004: 6). Изгледа да има. Литерарни одломци, романи у наставцима, научне анализе, општеполитичке студије или ускостручни прилози - сви ти текстови у основи се разликују од новинарских жанрова, а имају виши културни смисао, и доприносе позитивној психологизацији искуства масовног читаоца (РКТ 1992: s.v. В. и: Славковић 1975, Живковић 1963, Јовановић 2019).

2. Сем тога, у облике новинарског казивања укључују се и оптички и нелингвистички акустички системи знакова ${ }^{9}$, и сваки од ових знаковно-медијских облика у зависности је, разуме се, од информативне функције садржаја, од тежње новинара да постигне одређени психолошки ефекат. Дакле, може се рећи да друштвене околности креирају друштвену свест (Фром 2017) и психолошко понашање људи, те се медији постављају као моћно средство пропаганде ${ }^{10}$, оруђе којим је могуће свакодневно, па и у сваком тренутку дефинисати јавност и човекову социјалну и психолошку позицију у њој. Укупност конзумената, тј. 'циљна група', социјална средина, психолошки миље или сл. - чине медиолошку публику, а посеоне психолошко-социјалне групе примарни су 'потрошачи', али не и једини.

${ }^{8}$ Представе медијске културе показују ко има моћ а ко је нема, коме је допуштено да употребљава силу и насиље, а коме није. Несрећа је што у савременој медијској култури доминантни информативни и забавни медији представљају суштински и извор културне педагогије; они нас у великој мери уче како треб́ да се понашамо и шта треба да мислимо, осећамо, верујемо, чега да се плашимо и шта да желимо - а шта не (исп. о томе више у: Јовановић 2019).

${ }^{9}$ Некад су језгро друштвених норми чиниле религија, наука, уметност и филозофија као општи облик свести (исп. Лотман 1999). Свест савременог човека о себи и о друштву које га окружује формира се, међутим, у непрекидној комуникацији свих врста и нивоа. На тај начин она се мења и обликује.

${ }^{10}$ Венс (1994) говори о тзв. 'скривеним убеђивачима' када расправља о пропаганди. 
3. Према томе, социјалне детерминанте, заједно са психолошким, битно су укључене у процес ${ }^{11}$ одашиљања и пријема поруке уопште, а медијске посебно. Оне, у суштини, чине ограничавајуће факторе ефеката поруке појединца као припадника друштвене групе, нарочито ако се овоме придружи и идеолошко деловање. И у овом последњем моменту медији се показују као моћан инструмент социјалне контроле, и као један од главних државних идеолошких апарата који доприноси очувању хегемоније и 'колективно уравнотежене' психологије. Ова нас чињеница нужно уводи у домен тзв. политичке комуникације, а она је и те како обележена психологизацијом као специфичним видом перспективизације садржаја. Овде је понајмање реч о посматрачкој функцији, тј. простом информисању грађана - реч је, заправо, о обезбеђивању платформе за јавни политички дискурс, давању публицитета владиним и политичким институцијама, њиховом стављању у функцију канала политичких ставова и психолошког стања који се често назива 'колективном психозом'. Тако један облик комуникације, који сматрамо медијским - постаје, пре свега, психолошки филтер, али и економски, тржишни, политички и сл., кроз који пролази догађај пре него што се понуди јавности.

a) На овај начин се креира тзв. 'псеудодогађај' (Борстин 2003а, 2003б) - у чијој је основи тенденција медија да приказују неистините догађаје. Чист облик псеудодогађаја су партијске конференције, које медији преносе фрагментарно. Конференције за штампу су још један облик псеудодогађаја где политичар креира изјаву за јавност пре новинарске публике, а затим је преносе путем медија (Јовановић 2019). Уопштено речено, активности информацијског менаџмента, везане за владајућу политику, осмишљене су да би психолошки контролисале проток информација из институција владе у јавну сферу. Сви ови психолошки усмеривачи воде ка тзв. медијском империјализму. Тако се идеологија поставља као кохерентан скуп уверења и вредности које владају у једној култури, те се она нужно бави односима у оквиру друштва и моћи (Бретон 2000, Волков 2002).

б) Идеологију је, можда, најбоље схватити у дискурзивном смислу као идеју, значење, теорију - онако како то чини Стјуарт Хол (1976), и онда томе претпоставити одговарајуће облике размишљања, психологије свести и разумевања друштвених односа. Попут Хола, и Сосир (1969) и Барт (2015) сматрају да је значење дискурзивни процес који оперише унутар језичког система оптерећен поступком идеолошког означавања. Психолошко-социјална комуникација, заснована на овим уверењима - одиграва се у пресеку тзв. 'доминантног кода' и 'договореног кода' (као договореног читања), те и тзв. 'опозиционог кода' - као супротно читање и потпуно неслагање са значењима које је пошиљалац намеравао да пренесе.

\footnotetext{
${ }^{11}$ Исп. Јакобсонов комуникативни модел (Јакобсон 1966).
} 
в) У својој књизи Филозофија меgија Дивна Вуксановић (2007) полази од става да је свет масовних и нових медија конститутиван за данашње схватање реалности. Па и специфична естетизација стварности има своју психолошку детерминацију, јер је доживљај реалности, чулан по пореклу, и привидан по сазнајном значају, - аутореферентан и опажајно самоутемељен. Успостављена спрега између културе медија, психологије и идеологије отвара могућност хибридизације стварности, а она је лажно естетизована, и нужно се подређује тржишту, тј. увод је у свет популарне културе. У том контексту, сама лепота мора се схватити као производ стандардизован по узору на медијске, тржишне и технолошке матрице савременог света. Постаје јасно да естетизација медијски посредованог реалног трансформише са̂м појам лепоте, подређујући га стандардима прихваћеним унутар одређене лингивстичке и психолошке заједнице, продукујући нове модалитете који се генеришу по принципу једноставности и утилитарности.

4. Разматрајући однос медија и мита, Ролан Барт (2015) сматра да сваки знак неког језика може као означавајуће учествовати у изградњи мита као другостепеног система. Његова схватања су значајна у значењској анализи психологије медијских текстова. 'Означавајуће' мита истовремено је и смисао и форма, а однос који везује 'појам' и 'смисао' постаје однос искривљавања, те је процес митологизације стварности таква знаковна активност која је лишена значењског континуитета, таутолошки структурирана, обележена нинизмом $^{12}$ и квантификацијом квалитета. И ту се отвара простор за психолошку манипулацију. За Филипа Бретона (2000) психолошка манипулација у медијима увек је са етичког становишта срамна и нечасна, и представља претњу демократском друштву. Једна од главних стратегија манипулације по њему - јесте ограничавање слободе да се расправља или успротиви оном што му се предлаже (о томе и у: Милетић 2011: 13-31). Наметањем мишљења, на силу се жели продрети у нечији дух да би се тамо усадило неко мишљење или понашање а да човек није свестан присиле. У свакодневној комуникацији оваква манипулација је најчешће афективна, али је врло често когнитивна, тј. ослоњена на сазнајни аспект људске свести, и тиме се обезбеђују услови за тзв. 'медијски империјализам'.

\section{3. ДРУШТВЕНИ АСПЕКТИ ПСИХОЛОШКЕ ПЕРСПЕКТИВИЗАЦИЈЕ КОМУНИКАЦИЈЕ}

1. Колективна свест је једна од најбитнијих социјалних чињеница у комуникацији, јер је управо она амбијент опстојања појединих система кул-

${ }^{12}$ Реч је о томе да одмеравањем две супротности сазнање буде конституисано тако да обе буду истовремено одбачене. 
турних појава, као што су језик, религија, наука, политика и тако даље. Ови системи јесу реалности, иако се не могу непосредно примати чулима: своје постојање доказују тиме што у односу на емпиријску реалност манифестују нормативну моћ: тако се, на пример, одступање од језичког система, смештеног у колективној свести, спонтано доживљава и оцењује као грешка. И област естетског и психолошког јавља се у колективној свести пре свега као систем норми. Друштвени тренутак је колективну свест и психологију савременог човека учинио таоцем информације: савремени човек ухваћен је у мрежу сопствене тежње да се развија и учи. У сталној, колективној инерцији, којом се преплићу и саплићу држава и друштво, створила се посматрачка позиција овог вишесмерног процеса. Та тачка посматрача зове се 'јавност'. Да јавност не би остала пука формалност, формира се 'јавно мњење', појавни облик јавности, опипљива чињеница у којој информација, психолошки кодирана, постаје комуникација. Различите, како примарне, тако и секундарне потребе људи задовољавају се или се артикулишу у процесу комуникације, а за њихову реализацију или пак осујећење, потребна је друга особа, или група. Задовољење ових потреба ${ }^{13}$ омогућава јављање потреба за љубављу, наклоношћу и припадањем, те и потребе да се савлада распрострањено осећање отуђености, усамљености, несопствености и самоће.

2. У складу са својим поимањем људских потреба као израза нагонских порива, Фројд (1988: 18) изјављује да „задовољавање нагона представља срећу", те да се све друштвене запреке потребама, постављене у виду културних установа и регула ${ }^{14}$ - пред људском индивидуом постављају као проблем „индивидуалне економије либида” (1988: 23). У веку високе технологизације друштва, потрошачки оријентисаних, растрадиционалисаних појединаца, појачан је јаз међу генерацијама, ишчезао је осећај присности, а односи међу људима сведени су на хладну површност. И управо ту се почиње генерисати социјална патологија. Садржаји властитог културног наслеђа - о којима говори Исидора Секулић (1966) - почињу се донекле мењати и прилагођавати постојећим приликама, схватањима и тежњама (Симић, Јовановић 2002), а то није могуће изван језичког модалитета. Политичка или друштвена производња идеја, представа, свести - строго су прожете језичком производњом на исти начин на који су прожете и материјалном производњом. Дакле, религија, право, морал, наука, уметност, итд. (Виготски 1975), вербализују се кроз утврђене друштвено-културолошке обрасце, које називамо друштвеном свешћу.

${ }^{13}$ „Потреба за цењењем јавља се као последица задовољења претходних потреба. Задовољење потребе за самопоштовањем доводи до осећања самопоуздања, вредности, снаге, способности, довољности, осећаја корисности [...]. Потреба за цењењем јавља се као жеља за добрим гласом, односно, престижом, статусом, славом и сјајем, влашћу, признањем, достојанством и уважавањем" (Томић 2003: 36).

${ }^{14}$ Фројд (1988: 25): „[... .] наша такозвана култура сноси велики део кривице за нашу беду”. 
3. Сви облици културе, према томе, сустичу се, и генеришу - у друштвеној свести (исп. Хабермас 1963, Сапир 1992), и при томе и друштвена свест и језик губе првобитна обележја једноставности и унутрашње кохезије, па су - мисли Емил Диркем (1972: 96) - и све непостојанији. Јасно је да су све друштвене потребе диктирале и човекове културолошке и комуникацијске промене. Када потребе ${ }^{15}$ почну изазивати свест о неопходности и сврсисходности планског задовољавања, настаје 'култура', а то је један од аспеката друштвене свести. По свој прилици је и та духовна појава с временом, слично осталим културним вредностима, доживљавала пенетрацију и митску фетишизацију.

a) Као што видимо, когнитивни феномени у комуникацији су примарни, јер настају као последица подмирења основних потреба, док су сви остали типови когниције секундарни, иако су, заправо, делотворнији и реалистичнији (будући да они тестирају реалност). Јачање интуитивних моћи често за собом повлачи и јављање мистичних доживљаја, те се у комуникацији срећемо са непредвидивим надахнућима и увиђањима. Свако удаљавање од нарцисоидности побољшава поглед на свет, и утире пут стваралачкој и креативно ${ }^{16}$ вербализацији. Оваквој хабитуалној и језичкој креатибилности одупире се веома јака сила духовне конвенционалности, конзервативизма и стереотипије.

б) Симулација и хиперреално узима се за парадигму психолошког разумевања стварног и привида (Бодријар 2004: 2007). Наиме, укидањем референцијала, започиње ера симулација. Можда ју је најбоље разумети као вербатолошку производњу помоћу модела, нечег нестварног без порекла и стварности, нечег надстварног. Више није реч о илузији, дуплирању или пародији, реч је о замењивању стварног његовим знацима. Супротно представи, симулација полази од утопије принципа еквивалентности, те се читаво здање саме представе приказује као симулакрум. Тако настаје хиперреално, у коме масовни медији настављају деструкцију друштвене психологије, и постају извршиоци имплозије друштвеног у масама.

\footnotetext{
${ }^{15}$ „Задовољење примарних потреба утиче и на црте карактера, у том смислу што доноси више спокојства, ведрине, душевног мира, несебичности, великодушности, ширине, самопоуздања, осећања пријатељства према другим људима, толеранције” - запажа 3. Томић (2003: 38). Очигледно је да задовољење потреба утиче на развој најпозитивнијих психичких, карактерних и социјалних особености човека. Омогућава му „више храбрости, психичког здравља, истинске демократичности, опуштености, природности и већег уживања у одговорности” (Томић 2003: 39).

${ }^{16}$ Де Сосир (1969: 92) сматра да у језику обичај доминира над слободом делања, правило над креативним умом, прошлост над садашњошћу. У овој интерпретацији језик зависи од културе, како у смислу функционалном, исто тако и вредносном: експресивни, естетски и други моменти тога круга - културолошког су постања - а језик је само њихов преносник на међукултурним и међуиндивидуалним просторима (на истој линији закључивања је и Р. Симић. - УП. Симић 2010).
} 


\section{4. ЗАКљУЧНЕ НАПОМЕНЕ}

1. Дистинкција између друштвене свести, погледа на свет, колективног мишљења итд., на једној страни, и духовне културе, на другој, тешко да је ограничена на парцелацију расположиве симболичке грађе. Вероватно је боље ослонити се на функционалну перспективу. По Милићевом одређењу (1986: 530-531), друштвена свест свој смисао има у друштвеној оријентацији људи у савременим условима живота, и процени садашњих и прошлих вредности са тога гледишта, док култура у први план износи људску креативност (делатну перспективу односа према садашњим и наслеђеним вредностима). При томе се у покрету и на једном и на другом плану могу наћи исти симболички (суб)системи којима располаже дата друштвена средина. Слична се дистинкција успоставља нпр. између погледа на свет и самосвести. Улога самосвести према томе је регулативна, јер је она највиша контролна инстанца људске свести која служи осмишљавању осталих духовних функција - како искуствених, тако и идејних, једном речи: културолошких, комуниколошких и психолошких. Успостављајући равнотежу између искуствених и идејних, или између нагонских, прагматичких итд., и етичких итд. фактора понашања појединца и друштвене групе - самосвест је усредсређена на опстанак појединца. У свему томе комуникацијски моменат је веома важан.

2. Пријем, прерада и одашиљање информација заузимају доминантно место у социјалном и психичком животу савремене цивилизације. Човек се, између осталог, животно оријентише према основним вредностима око којих су организовани духовни и културолошки системи од којих је сачињена друштвена свест. Доминација једних или других од тих вредности, ствар је - наравно - 'избора', навика, моде итд. Али не може се потиснути или искључити утицај других. Фројд (1988: 16-17) препознаје извесну равнотежу, али њену тачку поставља врло ниско на лествици људских животних манифестација: између нагона и њиховог остварења. Разум, по овоме схватању, не успева да продре кроз шуму техникализованих, вештачких система и објеката, које је човек изградио да омогући себи материјално благостање и духовно задовољство. Свему томе као да је крива концептуална инсуфицијенција човекових моћи поимања, и његова немоћ да (у свему) прати технички напредак.

3. Вербатолошки облици комуникације у различитим говорним и текстолошким остварењима (Бал 2000) - делом су директни резултат когнитивне активности човекове, а делом прераде ове грађе по мотивационим регулама колективног искуства и општег мишљења, идеолошких уверења, предрасуда, тежњи и интуитивних спознаја, односно 'културе' колектива којем говорник 
припада, и његове личне (опште и уметничке, имагинативно-стваралачке) ${ }^{17}$ моћи духа.

а) Културни производи - ако желе да постигну успех - морају бити прихваћени од потрошача. Кључни фактор за њихово прихватање јесте могућност алтернативног читања. С једне стране, јавља се семиотички отпор као резултат супротних значења из текста, с друге стране - еванзивни отпор, који избегава свако наметање значења унутар текста. Џон Фиск (2001) сматра да се на овај начин обликује тзв. 'популарна култура', и он чак сугерише афирмативни однос према овом облику културе, те уводи категорију 'произвођача популарног ауторског текста', таквог текста који се нуди популарној производњи, и који је део популарне културе. У суштини, популарна култура није лишена семиолошког богатства, као нпр. фолк култура, која настаје као производ сразмерно стабилног традиционалног друштвеног поретка и коју карактерише друштвени консензус. Популарна култура увек је индустријализована и припада обичним људима.

б) Д. Келер (2004: 52) се залаже за успостављање теоријског модела „који културу схвата као спектар, и примењује сличне критичке методе на све облике културе, од опере до популарне музике, од модернистичке књижевности до сапунских опера". Уосталом, и језичка материја је - без обзира на дистинктне појединости или слојеве језичких чињеница - заједничка свима његовим творевинама, а чини је природни језик датога колектива. А језичка материја је подложна афективној манипулацији, у којој је главни поступак завођење, демагогизација, експресивизација поруке и сл., и когнитивној манипулацији, у којој је главни поступак тзв. манипулаторско кадрирање, а оно је засновано на човековој потреби да своје ослонце гради на чињеницама у које верује. Том се приликом истина преображава у лаж и обрнуто, чињенице се преокрећу тако да се стварност свесно изобличава.

4. Може се закључити на крају да језички, културолошки и психолошки обрасци делују на неком плану координирано, и узајамно се подржавају, прожимајући духовни живот чланова колектива (в. Головин 1977). У ситуацији када та подршка изостане, комуникација бива 'напорна и компликована'. Традиција, дакле, оснажује и оптимализује комуникацију, активира духовне потенције говорника, те је психолошки 'уложена' и утрошена енергија у

${ }^{17}$ Тумачећи погледе Ернста Касирера (1985: 51), Р. Симић и Ј. Јовановић (2002: 228) утврдили су „да Касирер увиђа, прво, да је култура на неки препознатљив начин изграђена из дискретних састојака; да ти састојци, друго, имају сопствену структуру; да је та структура, треће, уобличена 'мрежом многоструких веза' [...]”. Ти састојци 'културе', тј. колективног мишљења, стално су у позадини мисаоних процеса, сусрета са конкретним искуством, које бива препознато и на дати начин вредновано тек на позадини културног система - и језичком продукцијом појединца и колектива. Језички облици настају активирањем залиха из језичког система, а ове су у чврстом додиру са духовним залихама које подржавају језик и у систему и употреби (исп. и СоТНК 1977: 1-140). 
комуникацији директно пропорционална степену културе датог колектива. Количина и квалитет наталожених 'психолошких потенцијала' језичких јединица у колективној свести и свести појединца - мера је културе друштва и језичке култивисаности његових чланова.

\section{ЛИТЕРАТУРА} knjiga.

Бал (2000): M. Bal, Naratologija: teorija priče i pripovedanja, Beograd: Narodna

Барт (2015): Р. Барт, Елеменӣи семиолоїије, Београд: Библиотека ХХ век.

Белић (1998): А. Белић, Његош и национална култура наша. О великим ствараоцима, Изабрана gела 6, Београд: Завод за уџбенике и наставна средства, 122-146.

Бенедикт (1934): R. Benedict, Patterns of Culture, Boston: Houghton Mifflin. hipelag.

Бодријар (2004): Ž. Bodrijar, Pakt o lucidnosti ili inteligencija Zla, Beograd: Ar-

Бодријар (2007): Ž. Bodrijar, Duh terorizma, Beograd: Arhipelag.

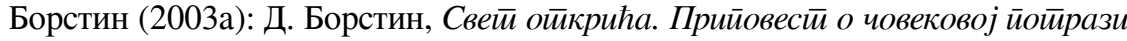
за сйознајом свейа и самої себе, Београд: Геопоетика.

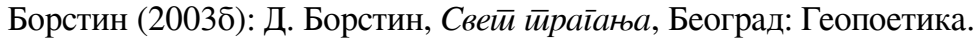

Блумфилд (1970): L. Bloomfield, Language, London: University Books.

Бретон (2000): Ф. Бретон, Изманийулисана реч, Београд: Clio.

Венс (1994): П. Венс, Скривени убеђивачи, Београд: Грмеч - Привредни преглед. звежђа.

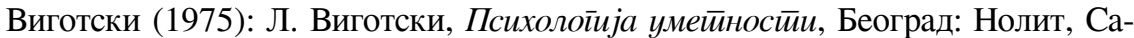

Волков (2002): В. Волков, Дезинформација, Београд: Наш дом.

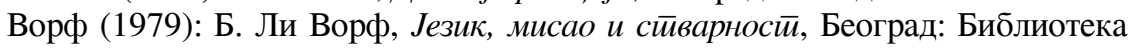
$\mathrm{XX}$ век.

Вуксановић (2007): Д. Вуксановић, Филозофија меgија: онйолойија, естиейика, крийика, Београд: Чигоја.

Вучковић (1995): П. Вучковић, Оїлеgи из семанӣике и йраймайике, Београд: Савремена администрација.

Головин (1997): С. Ю. Головин, Словарь практического психолога, Минск: Харвест.

Диркем (1972): E. Dirkem, O podeli društvenog rada, Beograd: Prosveta.

Еко (1973): У. Еко, Кулӣура, информација, комуникација, Београд.

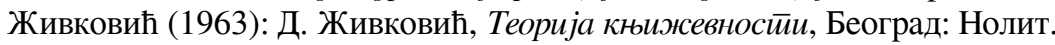

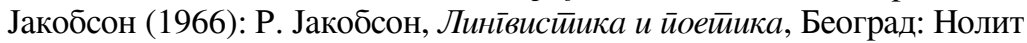

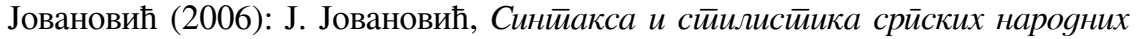
йословица I-II, Београд: Филолошки факултет у Београду - НДСЈ - Јасен.

Јовановић Симић, Симић (2015): Ј. Јовановић Симић, Р. Симић, Вербайолоімја, Београд: Јасен.

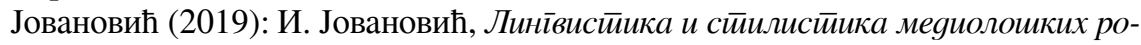
gова и врсииа, Београд: Јасен.

Катлин (1998): R. Kathleen, Interpersonalna komunikacija - gdje se misli susreću, Zagreb: Alinea. 
Келер (2004): Д. Келер, Меgијска кулӣура, Београд: Clio. knjiga.

Леви-Строс (1989): C. Levi-Stross, Strukturalna antropologija, Zagreb: Školska

Леонтјев (1979): А. А. Леонтьев, Высказивание как предмет лингвистики, психолингвистики и теории коммуникации, Синтаксис текста, Москва, 39-52.

Лотман (1999): Ј. Лотман: Кулйура и ексйлозија, Варшава: Жилко.

Милетић (2011): М. Милетић, Комуникационе стратегије - покушај теоријске концептуализације. Комуникације, медији, култура, Гоgишњак Факулйейа за кулйуру и меguје, бр. 3, Београд: Мегатренд универзитет, 13-31.

Милетић, Милетић (2012): М. Милетић, Н. Милетић, Комуниколошки лексикон, Београд: Мегатренд универзитет.

Милић (1986): V. Milić, Sociologija saznanja, Sarajevo: V. Masleša, Logos.

Морис (1975): Ч. Морис, Основе тиеорије о знацима, Београд: БИГЗ.

Мршевић-Радовић (2008): Д. Мршевић-Радовић, Фразеолоіија и национална кулйура, Београд: Друштво за српски језик и књижевност.

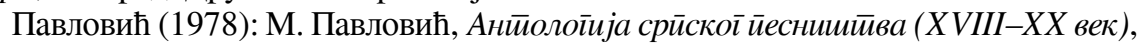
Београд: СКЗ. Београд.

Радојчић (1975): Светозар Радојчић, Узори и gела сйарих срйских умейника,

РКТ (1992): Речник књижевних иеермина, друго, допуњено издање, Драгиша Живковић (ур.), Београд: Нолит.

Рубинштејн (1973): S. L. Rubinstein, Grundlagen der allgemeinen Psychologie, Berlin: 'Volk und Wissen', 8. Aufl.

Сапир (1992): Е. Сапир, Језик, Нови Сад: Дневник.

Секулић (1966): И. Секулић, Говор и језик, кулйурна смойра нароgа, Нови Сад: Матица српска.

Симић (1992): Р. Симић, Увоg у филозофију сйила, Београд: Универзитет у Београду.

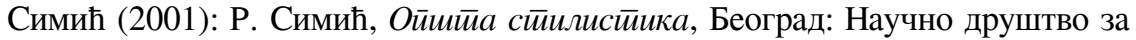
неговање и проучавање српског језика.

Симић, Јовановић (2002): Р. Симић, Ј. Јовановић, Основи иееорије функционалних сииилова, Београд: НДСЈ - Јасен.

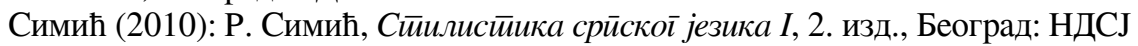
- Јасен.

Славковић (1975): Д. Славковић, Основи новинарсӣва и информисана, Београд: Радничка штампа.

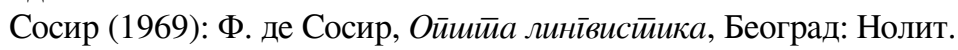

СоТНК (1977): Савјетовање о терминологијама народне материјалне и духовне културе, АНУБиХ, Посебна издања ХХXI, Сарајево, 1-140.

Спенсер (1924): H. Spencer, Philosophy of Style (An Essay), New York and London: D. Appleton and Co.

Стјуард (1981): Х. Стјуард, Теорија кулйурне йромене, Београд: Библиотека $\mathrm{XX}$ век.

Томић (2003): 3. Томић, Комуниколойја, Београд: Чигоја.

Удинг, Штајнбринк (2001): G. Ueding, B. Steinbrink, Grundriss der Rhetorik, Germany: Berlin. 
Ферт (1957): J. R. Firth, Papers in Linguistics 1934-1951, London - New York Toronto: Oxford University Press.

Фиск (2001): Dž. Fisk, Popularna kultura, Beograd: Clio.

Форд (1949): C. D. Forde, Habitat, Economy and Society, London: Methuen.

Фројд (1988): S. Frojd, Nelagodnost u kulturi, Beograd: Rad.

Фром (2017): E. From, Zdravo društvo, Beograd: Nova knjiga.

Хаסермас (1963): J. Habermas, Tehnika i znanost kao ideologija, Zagreb.

Хартман (1924): К. Р. Хартман, Philosophy of the Unconscious (1869). - Цит. по: Спенсер 1924.

Хелер (1978): A. Heler, Svakodnevni život, Beograd: Nolit.

Хол (1976): Е. Хол, Неми језик, Београд: БИГЗ.

\author{
Ivana R. Jovanović \\ Philology High School \\ Belgrade
}

\title{
ON SOME ASPECTS OF PSYCHOLOGY OF MEDIA AND GENERAL COMMUNICATION
}

Summary: The paper discusses the interpenetration of social consciousness, culture, psychology and communication, from the methodological point of view in which the notion of culture is considered as much broader than the one of social consciousness. Collective consciousness is not understood here primarily as a psychological reality, but as a social fact, an environment in which language, religion, science, politics, etc. survive, and the psychological field in the collective consciousness is defined as a system of norms. Regarding psychological elements in media communication, the author points out that acquiring the ability to interpret and criticize media manipulations significantly helps individuals create a better relationship with the dominant media and culture in general. Establishing a link between media culture, ideology and psychology - the author concludes - opens the possibility of hybridization of reality, and regression of human ideals.

Keywords: psychology, communication, sociology, mediology, manipulation. 